\title{
O BOM DIABO NA LITERATURA DE CORDEL
}

\author{
Renata Siuda-Ambroziak* \\ Universidade de Varsóvia - UW/ Polônia \\ r.siuda@uw.edu.pl
}

\begin{abstract}
RESUMO: No artigo a autora pretende demonstrar, aproveitando como exemplos fragmentos dos folhetos de literatura de cordel nordestina, que, apesar do Diabo/Demônio/Satanás ser na tradição judaicocristã uma criatura racional, incorpórea, que tem por objetivo a maldade, ele aparece muitas vezes na literatura de cordel como um personagem amistoso, compreensível frente às falhas humanas, às vezes até tentando prevenir os homens de errar e acabar no inferno superpovoado. Os poetas populares da literatura de cordel sabem apresentar o Diabo de uma perspectiva contrária à fé cristã e à doutrina católica, quase como amigo dos homens, companheiro em dificuldades e desgraças deste mundo. Ao mesmo tempo, fazê-lo sem perder qualidades demoníacas de assombrar e assim, provocar conversões, cumprindo desta maneira nas narrativas populares em verso uma função importantíssima: a de socialização no quadro normativo cristão do sistema de crenças tradicionais inerentes à religiosidade popular do Nordeste. A sui generis "subcultura" regional forte do catolicismo brasileiro, vigente ainda hoje nas camadas populares.
\end{abstract}

PALAVRAS-CHAVE: Diabo - literatura de cordel - mal - bondade

\section{THE GOOD DEVIL IN THE FOLK STRING LITERATURE}

\begin{abstract}
In the article the author, taking advantage of some excerpts taken out of the string literature of the Northeastern region leaflets, aims at demonstrating that, although the Devil/Demon/Satan is in the Jewish-Christian tradition as a rational, disembodied creature whose aim is evil, it often appears in string literature as a friendly figure, understanding the faces of human failings, sometimes even trying to prevent them from making mistakes and ending up in the overpopulated hell. It seems that popular poets know how to present Devil from a perspective contrary to Christian faith and the Catholic doctrine, almost as a friend of humans, a companion in difficulties and misfortunes of this world. At the same time, causing him without losing the demonic, terrifying qualities, necessary for leading human beings towards conversions, while, at the same time, fulfilling an important function: the one of socializing within the
\end{abstract}

Pós-doutora em Sociologia pela Universidade Federal de Santa Catarina, doutora em Filosofia Social, mestre em Estudos Sociais com especialização na área de Estudos em História Social da América Latina, bacharel em Filologia Inglesa (especialização: metodologia do ensino). Professora do tempo integral, dedicação exclusiva no Centro dos Estudos Americanos, integrante do Grupo de Pesquisa sobre América Latina e o Caribe, coordenadora do Laboratório dos Estudos Brasileiros, trabalhando com os seguintes temas: transformações religiosas, religiosidades, mercado religioso - análise sociológica e cultural, religião no Brasil e relações entre a religião e política, cultura latino-americana, questões e políticas migratórias, identidades étnicas, migrações e religião, descendentes dos poloneses no Brasil. 


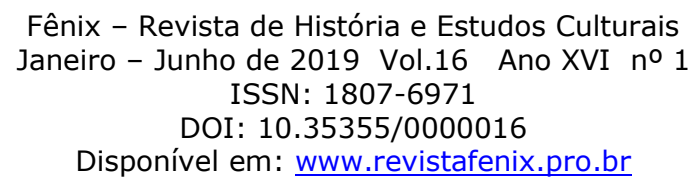

normative Christian framework of traditional creeds inherent to the popular religiosity in the Northeastern region. The sui generis, strong, regional "subculture" of Brazilian Catholicism, still alive today in the lower social strata.

KEYWORDS: Devil - string literature - evil - goodness

\section{INTRODUÇÃO}

A presença do Diabo e o imaginário sobre ele é algo natural e cotidiano precisamos explicar, por meio da existência dos espíritos malignos, a violência, o sofrimento, a infelicidade, e expressar os nossos temores e desgraças. O mal personificado na figura do Diabo, do Demônio, do Satanás é característico especialmente para o imaginário social de tradição religiosa judaico-cristã, tocando frequentemente nos temas da polaridade entre Deus e o Diabo, o Bem e o Mal e demonstrando assim a vertente maniqueísta do mundo e da vida humana. ${ }^{1} \mathrm{O}$ ensinamento do Cristianismo em relação ao Demônio não deixa a menor dúvida quanto à sua existência (e a de diabos em geral, que são múltiples) - ele é o ser espiritual, inteligente, criado por Deus, que se revoltou contra o seu Criador. ${ }^{2} \mathrm{O}$ Diabo/Demônio/Satanás é, portanto, uma criatura racional, incorpórea, que tem por objetivo a maldade.

A história do Diabo e a sua origem, historicamente, parece bastante obscura: a Bíblia não oferece uma chave explicativa clara para a identidade de quem se tornou responsável pela infelicidade da humanidade. Pela primeira vez o nome Satã aparece no livro de Jó (Jó 1,2) como nome próprio de um espírito, que age seguindo as ordens e a vontade divinas, sendo o inimigo dos homens, mas não necessariamente de Deus fazendo para o Criador o "trabalho sujo" que precisava ser feito. O Velho Testamento

\footnotetext{
1 A cosmologia maniqueista fala sobre uma luta entre o Reino da Luz e o Reino das Trevas, que permeia tudo e terminará com o retorno de Jesus e a grande batalha entre as forças do Anticristo e os regimentos celestiais. No entanto, existem outras percepções da personificação do mal, por exemplo nas religiões afro-brasileiras ela é diferente da visão cristã: os exus não habitam o inferno nem são espíritos das trevas - são espíritos da rua que, por se encontrarem na terra, servem de intermediários ou mensageiros dos orixás. Eles são muito interesseiros: por meio do "pagamento" oferecem a sua proteção a todos que querem tomar as medidas protetoras contra o mal. Mas os exus tanto protegem, como se vingam ou fazem o mal a pedido de alguém que faz uma oferenda (um "trabalho") para prejudicar o seu inimigo. Nas religiões afro-brasileiras não há, portanto, lugar para o maniqueísmo moralista que caracteriza as religiões cristãs.
}

2 KALVERKAMP, Desidério, KOPPLENBURG, Bonaventura. Ação pastoral perante o espiritismo. Petrópolis: Vozes, 1961, p. 178. 


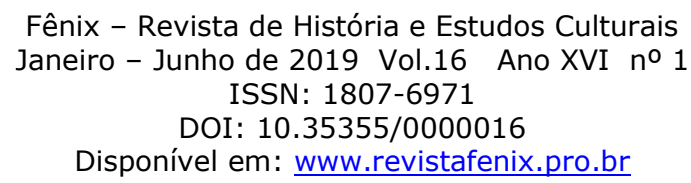

não menciona nada que pudesse oferecer alguma base sólida para a doutrina demonológica. ${ }^{3}$ As únicas alusões aos maus espíritos podem ser identificados com os deuses extrangeiros (Lev.17,7; Dt.32,17).

Já o Novo Testamento apresenta uma imagem do Diabo bastante ambígua como o inimigo de Deus e, ao mesmo tempo, realizador da sua vontade. Jesus expulsou demônios (Mt. 9, 32-34; Mc. 1,34), falou do fogo eterno preparado para o Diabo e os seus demônios (Mt.25,41), mencionou Belzebu (Mt.12, 26-27; Mc.2,23-25; Lc.11, 1520) e foi pessoalmente tentado (Mt.4,1-11; Mc.1,12-13; Lc.4, 1-13). A história da queda dos anjos aparece nos Evangelhos (Lc.10,8), na epístola de São Pedro (II Pdr.2,4) e no Apocalipse (Ap.12,7-9; 20,2). De todas essas menções foram estabelecidas algumas noções básicas sobre o Diabo na cultura ocidental cristã, persistentes até hoje: ele tenta e engana, provocando sofrimento, ele é a emanação do Mal personificado.

$\mathrm{Na}$ tradição literária européia a presença do Diabo é visível nas obras-primas de autores como Dante, Milton, Goethe, Blake, Mann, Marlowe. Na tradição lusitana Gil Vicente, em pelo menos onze das suas obras o Diabo aparece como figurante, fazendo uma contribuição respeitável ao tema de teor didático-moralizante, compondo uma série de personagens diabólicas, mais hilárias e sarcásticas que propriamente assustadoras.

Mas não é difícil perceber também a presença e a importância do Diabo na cultura brasileira (como legado da colonização portuguesa somado às contribuições indígenas e africanas), inclusive na sua língua e literatura. Somente na linguagem popular do Brasil foram contadas mais de cem expressões, sinónimos e apelidos em torno da figura do Diabo ${ }^{4}$, isto sem falar-se de algumas obras primas diretamente ligadas ao fenômeno, como é certamente "Grande sertão: Veredas” de Guimarães Rosa,

Contudo, a Bíblia fala sobre bruxaria (Lev.20,27; Dt.18, 10-11; I Sam.18, 8-9) ordenando que os culpados sejam apedrejados até a morte (o que provocou as futuras perseguições), mas sem vínculo explícito entre a bruxaria e os demônios. Os processos de bruxaria foram ainda esporádicos na Idade Média, com a sua verdadeira explosão na segunda metade do século XVI e a primeira do século XVII, vinculada às guerras religiosas que seguiram a Grande Reforma. As práticas das bruxas serviam como metáfora do Mal e uma importante parte da estrutura teórica da demonologia, que começou com a Bula Summis Desiderantes Affectibus do Papa Inocêncio VIII e o tratado demonológico Malleus maleficarum de Heinrich Institor e Jacob Sprenger (1486), seguido pela abundante literatura (MICHELET, Jules. Sobre as feiticeiras. Lisboa: Afrondite, 1974, pp. 180-190).

4 SOUTO MAIOR, Mário. Território da Danação: o diabo na cultura popular do Nordeste. Rio de Janeiro: Liv. São José, 1975. 
com o seu subtítulo: “O diabo na rua, no meio do redemoinho...”. Como explica Cândido:

Guimarães Rosa entra resolutamente no plano mágico, sugerindo para os comportamentos decisivos um substrato simbólico, dissolvendo-os em comportamentos primordiais, até trazer à baila, como signo máximo que percorre todo o livro desde a epígrafe, o arquétipo de todas as divisões do ser: o Demônio. ${ }^{5}$

Na sua classificação de contos populares brasileiros, L. de Câmara Cascudo chega até a destacar como categoria separada o tema do "Diabo logrado", em razão da sua presença nas inumeráveis lendas, narrativas e romances. ${ }^{6}$ Mas é na literatura popular, especialmente de cordel, onde o Diabo constitui um dos personagens centrais das histórias, imprescindível na explicação dos eventos, situações e comportamentos humanos. $^{7}$

A literatura de cordel, vendida em feiras, praças, mercados, entre outros lugares, feita por poetas populares, locais em versos (na maioria das vezes em sextilhas, septilhas ou décimas), com as capas que são ilustrações a partir de um molde impresso em uma matriz de madeira, é, portanto, uma fonte rica e acessível das informações sobre a percepção popular da figura do Diabo, com as suas imagens muito mais coloridas do que aquelas encontradas nas obras doutrinárias, mostrando um verdadeiro fascínio e a importância do "motivo diabólico" na cultura e religiosidade do sertão brasileiro. O interessante, no entanto, é que o Diabo aparece frequentemente na literatura de cordel, como pretendo mostrar, ao mesmo tempo fora e dentro do padrão geral estabelecido na cultura cristã. Não necessariamente como alguém muito temido, mas também como um ser transcendente "domesticado", fraternizado, amistoso, às vezes grotesco ou até aparentemente deprimido com o seu papel pejorativamente demoníaco. Bastante tolerante frente às fraquezas humanas, cordial e parceiro frente àqueles que se rebelam contra a ordem mundana, fazem perguntas difíceis ou buscam, por meio do seu próprio caminho, verdade, justiça, felicidade, alegria. Resumindo, ele é,

5 CÂNDIDO, Antônio. Tese e antítese. $3^{\text {a }}$ ed., São Paulo: CEN, 1978, p. XII-XIII.

6 CÂMARA CASCUDO, Luís. Geografia dos Mitos Brasileiros. 2a. ed., Rio de Janeiro: Olympio, 1976, p. 51-77. Um outro autor que pode ser consultado em relação ao tema da presença da figura do Diabo nos contos populares é, por exemplo, PIMENTEL, Altimão. O Diabo e outras entidades míticas no conto popular. Brasília: Coordenadora Edit. De Brasília, 1969.

7 CARVALHO, S.M.S., Jurupari. Estudos de Mitologia Brasileira. São Paulo: Atica, 1979. 


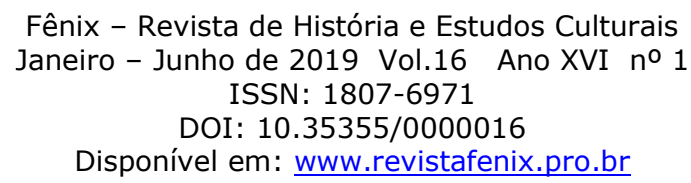

com frequência, oximoramente "o bom Diabo" - assim como apareceu recentemente, aliás provocando severo criticismo por parte da opinião pública, na literatura infantil. ${ }^{8}$

Procurando resposta à pergunta de que modo os poetas populares abordam nos seus folhetos a figura do "bom Diabo", neste artigo foco em demonstrar e analisar os exemplos da presença não tradicionalmente e uniformemente pejorativa desse personagem na literatura de cordel, que, como acredito, tem uma grande repercussão e uma forte influência no imaginário social dos brasileiros, especialmente na região nordestina, com a sua fortíssima religiosidade popular sincrética, interpenetrada por várias “impurezas da fé” de origens européias, africanas e ameríndias.

\section{O DIABO NÃ̃ TÃo MAU ASSIM...}

Existem vários livros sobre a temática do Diabo na cultura popular, inclusive na literatura de cordel. Mário Pontes admite até existência de um "ciclo de Diabo" na literatura popular em verso, identificando três momentos chave nessa relação: a transfiguração, o encontro e o pacto chamado "faústico", demonstrando como o Demônio acompanha as mais variadas transformações da sociedade brasileira na região nordestina; como este personagem influi ativamente, também por meio das obras de cordel, nas mudanças da mentalidade das pessoas e como impacta e preserva os importantes elementos da religiosidade popular do povo. ${ }^{9}$

O que, no entanto, parece muito mais pertinente aos objetivos deste artigo é que a figura do Mal personificado no Diabo cumpre nas narrativas populares em verso uma função importantíssima: a de socialização no quadro normativo cristão do sistema

8 Veja, por exemplo, o livro infantil da autoria de Paulo Bentancur (A máquina para brincar. Editora Bertrand Brasil, 2005), que provocou uma grande discussão nas mídia: http://www.administradores.com.br/noticias/cotidiano/livro-infantil-causa-revolta-por-apresentar-odiabo-como-um-bom-parceiro/89945/ (acesso 30.11.2018); http://www.popmundi.com.br/blogs/wille-uma-noticias/sou-ateu-autor-paulo-bentancur-fala-sobre-polemica-envolvendo-livro-de-poemas/ (acesso 30.11.2018); http://www.jornaldebrasilia.com.br/entretenimento/cultura/559123/livro-infantojuvenil-com-conteudo-controverso-causa-revolta-entre-maes-nas-redes-sociais/ (acesso 30.11.2018); http://gazetaonline.globo.com/_conteudo/2014/07/noticias/cidades/1492358-diabo-em-livro-infantojuvenil-vira-polemica.html (acesso 30.11.2018); http://cinenegocioseimoveis.blogspot.com.br/2014/07/livro-infantil-promove-satanismo-no.html (acesso 30.11.2018)

9 PONTES, Mário. Doce como o Diabo - Demônio, utopia e Liberdade na poesia de cordel nordestina. Rio de Janeiro: Codecri, 1979. Vale a pena reparar, no entanto, em relação à proposta do autor, que, sendo o Diabo um dos elementos centrais e permanentes na literatura de cordel, é dificil aplicar a própria noção do "cíclo" à este motivo literário. 
de crenças tradicionais inerentes à religiosidade popular do Nordeste - a, sui generis, "subcultura" regional forte do catolicismo brasileiro, vigente nas camadas populares. Por isso, em alguns versos dos folhetos da literatura de cordel que vou citar adiante, o essencial é o seu valor educativo: na maioria dos casos, a figura diabólica aparece para fornecer um certo padrão de comportamentos - um modelo lógico, socialmente e culturalmente aprovado, que visa a dar explicação a mecanismos subjacentes que operam nos fundamentos da existência individual e, ao mesmo tempo, coletiva, assim como para "despertar" os ouvintes para seguir uma nova vida, para mudar os seus comportamentos indesejados.

Por exemplo, no folheto do poeta baiano, Minelvino Francisco Silva, intitulado: "A mãe que xingou o filho no ventre e ele nasceu com chifre e com rabo em São Paulo", ele narra a história sobre uma mulher grávida, que fica reclamando da sua gravidez e se nega assistir aos serviços e liturgias comunitárias por causa da barriga, chamando o seu filho nascituro de "diabo" e assim justificando a sua preguiça e - a consequente ausência:

Eu so posso passear/ quando tiver este cão/ que veio me atrapalhar/ e fazer condenação (....) Só pode ser o diabo/ que tenho comigo aqui/ Que bole a noite todinha/ Quase não deixa eu dormir. ${ }^{10}$

A punição vem na forma de ela parir um menino "de rabo, asa e esporão/ com dois chifres na cabeça,/ pretos da cor de carvão." Um menino, que, aliás, nem o médico consegue "liquidar" com uma injeção aplicada ("daquelas que estermina/(...) para cortar sua sina/mas ele sorriu e disse:/ Para mim é vitamina") e que tem que ser "preso numa jaula de ferro". O autor, contando essa história, tenta convencer o ouvinte de que o Diabo tem que ser sempre repudiado e o nome dele - evitado de pronunciar, enquanto o de Deus - louvado e temido: "Deus é quem dá a saúde/E Deus quem nos dá o pão/Deus é quem nos dá a sorte/Deus é quem dá-nos o perdão/ E Deus quem nos dá a vida/E ainda dá a salvação". ${ }^{11} \mathrm{O}$ que parece, no entanto, interessante nessa história é que o mesmo autor do folheto, aplicando o tom tão sério e moralizador, com os objetivos educativos aparentemente fortes e claros e uma moldura normativa bastante rígida,

\footnotetext{
10 MINELVINO Francisco. A mãe que xingou o filho no ventre e ele nasceu com chifre e com rabo em São Paulo. (s.n.t., n.p)

11 Ibid.
} 
sozinho esteja desconfiando da plausibilidade da sua própria fala: "Se isto não for verdade/Esta história que rimei/Não sou eu o mentiroso/pois nada presenciei/Apenas estou vendendo/Pelo preço que comprei." O Diabo dele, apesar de espantar com as características físicas tipicamente associadas na tradição cristã ao Demônio, na realidade não é capaz de fazer mal a ninguém por sua conta, sozinho sendo "um pobre coitadinho": "Diabo é o pai da mentira/ Diabo não tem riqueza/ Diabo é o ente mais pobre/ Que ficou por natureza/ Perdeu a graça de Deus/ Ele é o autor da pobreza." 12

$\mathrm{Na}$ verdade, a punição da mulher acontece por causa da decisão soberana de Deus, é um castigo celestial cruel aplicado na criança dela, aliás inocente, que nasce com quase todos atributos físicos do Diabo criados no imaginário popular. O elemento demoníaco, aparecendo teoricamente como o polo oposto ao divino, não se mostra, portanto, independente de Deus e da sua vontade. É o próprio Deus, sozinho, que toma decisões e que "puxa todas as cordas", controlando as forças demoníacas, que agem segundo as ordens recebidas. Mas os folhetos da literatura de cordel, tendo no seu conteúdo muito mais inspiração demoníaca do que divina, nunca levam os humanos à rebelião diante do Criador. Ao contrário, tentam moralizar "apaziguando o espírito" dos personagens e, ao mesmo tempo, também dos ouvintes/leitores, preservando, na sua estrutura interna básica, a oposição maniqueísta e a visão do Diabo como o grande adversário de Deus - o Demônio, que constitui normalmente o pólo oposto ao sagrado na consciência coletiva dos cristãos.

Todavia, uma parte significativa das narrativas deixa entrever um outro lado, muito mais interessante para a minha análise, que é a presença cotidiana, constante e até simpática, ou, pelo menos, não tão perturbante, do Diabo bom, "humanizado" e aparentemente solidário com homens nas várias infelicidades e desgraças. Às vezes mostrando-se um ser cômico ou grotesco, caricaturizado numa sui generis "estetíca de feio", não tão temido, mas permanecendo mesmo assim suficientemente poderoso. Deus - omnipotente, omnisciente e omnipresente está, no entanto, menos presente na vida dos homens do que o seu adversário - o Diabo, que possui forças bem limitadas em comparação com as divinas. Por outro lado, o Demônio, até quando derrotado ou dominado, permanece inteligente e parceiro - apesar de que ele deveria ser, segundo o

12 MINELVINO Francisco. A mãe que xingou o filho no ventre e ele nasceu com chifre e com rabo em São Paulo. (s.n.t., n.p) 


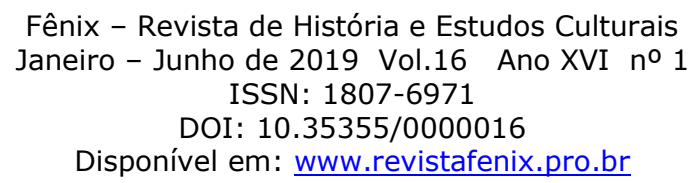

tom moralizador, evitado, a narrativa de cordel não consegue passar sem ele. Existem inúmeras histórias nas quais o Diabo é enganado e logrado, mas de qualquer maneira continua sendo percebido pelo leitor/ouvinte como um ser "legal", um verdadeiro companheiro na miséria dos homens, ou até mais uma vítima de opressão deste mundo o Diabo se apresenta, ao mesmo tempo, como o causador e o parceiro fiel nas desgraças humanas.

Nas "histórias de exemplo" apresentadas pelos folhetos de cordel, que seguem recorrendo aos mesmos elementos tradicionais dos casos exemplares da literatura medieval européia, o padrão comum das narrativas produzidas é o de "pedagogia de temor", de "aprendizagem por medo" - as narrativas são frequentemente elaboradas com objetivos claros e a finalidade de levar os descrentes a aceitar a fé cristã ou incitar/motivar os pecadores a voltar à Igreja. Nelas aparecem momentos em que os poetas põem a nu as contradições, desgraças e injustiças deste mundo, discutidas não tanto pelos homens-protagonistas que pelo Diabo, que não teme de fazer denúncias a Deus, seu adversário, mas também ao mesmo tempo seu patrão, em nome dos mais oprimidos e mais infelizes.

No folheto de Leandro Gomes de Barros "Peleja de Manoel Riachão com o Diabo", o poeta primeiro utiliza os recursos do cômico e grotesco descrevendo a figura do Diabo feio:

Riachão estava cantando,/ na cidade de Açu,/ quando apareceu um negro/ da espécie de urubu/ tinha a camisa de sola/ e as calças de couro cru./ Beiços grossos e virados/ como a sola de um chinelo,/ um olho muito encarnado/ e outro muito amarelo,/ este chamou Riachão,/ para cantar um martelo. ${ }^{13}$

para logo depois mostrar o lado bom do Demônio simpatizando com a humanidade e bastante crítico frente à ordem das coisas mundanas estabelecida pelo Criador:

Riachão, amas a Deus,/ sendo mal recompensando,/ Deus fez de Paulo um monarca/ de Pedro um simples soldado/ fez um com tanta saúde/ outro cego e aleijado./ (....) O teu vizinho e parente/ enricou sem

13 GOMES DE BARROS, Leandro. Peleja de Manoel Riachão com o Diabo. (s.n.t., n.p). 


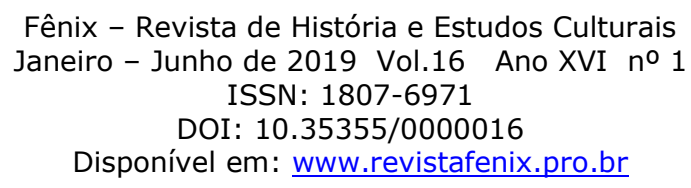

trabalhar,/ teu pai trabalhava tanto/ e nunca poude enricar,/ não se deitava uma noite/ que deixasse de rezar. ${ }^{14}$

Finalmente, não tendo sucesso nenhum em explicar ao seu companheiro a natureza das injustiças do mundo, o Diabo se rende e vai embora: "Arre lá! Lhe disse o negro/ você é caso sem jeito,/ eu com tanta paciência/ estou lhe ensinando direito,/ você ver que está errado/ faz que não ver o defeito", entendendo que o seu espírito de rebeldia, de revolta contra o estado das coisas na vida térrea não necessariamente está compartilhado pela humanidade submissa, que não quer entrar na luta contra a omnipotência divina e que, talvez, simplesmente não entenda o seu discurso.

Num outro folheto, intitulado "História de João da Cruz", da autoria do poeta Leandro Gomes de Barros, o autor conta a história de um jovem ateu, que um dia teve um sonho em que caminhava num deserto e se deparou com a necessidade de escolher um dos caminhos para seguir. Ele decidiu pela esquerda, que findava numa mansão demoníaca com a fumaça, cheiro de enxofre, serpentes, fogo e correntes. O Diabo mostrou o Inferno ao jovem, cuja visão terrível convenceu-o da necessidade de se converter e mudar de caminho para aquele à direita, que finalmente o conduziu ao lugar de beleza e felicidade. Infelizmente, depois de acordar ele foi informado do falecimento da sua mãe e por causa disso mudou a sua vida completamente, se arrependeu e iniciou uma longa penitência, marcada pelo aparecimento do Diabo que queria vencer a sua resistência por meio dos prazeres do sexo. O jovem fraquejou repentinamente, mas depois voltou à fidelidade a Deus e finalmente obteve a graça divina. Uma parte do folheto, aliás muito longo, de quase um mil quatrocentos versos, nos apresenta o monólogo do Diabo que contrargumenta o jovem durante a sua disputa:

Então disse o indivíduo:/ existe Deus, é verdade/ não como diz tua mãe/ qu'ele é de tanta bondade/ porque onde há orgulho/ só pode haver falsidade./ - E as coisas deste mundo/ já não tens observado?/ Pois um nascer tão feliz,/ e outro tão desgraçado?/ Por que abandona um,/ e outro é tão amparado?/ - Pois se Deus fosse tão bom,/ nasceria tudo igual,/ como nasce um para o bem/ e vem outro para o mal?/ Então a misericórdia/ não é para todos em geral! ${ }^{15}$

\footnotetext{
14 Ibid.

15 GOMES DE BARROS, Leandro. História de João da Cruz. (s.n.t., n.p)
} 


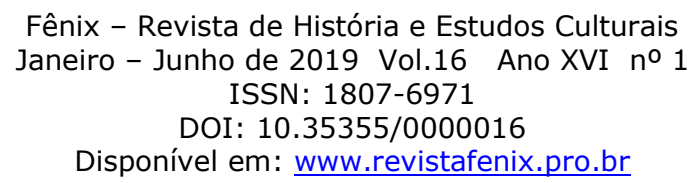

Existem também, na literatura de cordel, folhetos que mostram o pacto do seu protagonista com o Demônio, feito normalmente depois de uma vida difícil, cheia de miséria e sacrifícios, apesar de constantes apelos à misericórdia divina, orações ardentes e fidelidade a Deus. O pacto com o Demônio, na poesia popular, representa uma das poucas saídas acessíveis para homens que querem acabar com as suas desgraças e realizar os seus planos, sonhos e anseios, pedindo ajuda ao adversário do Deus. Isso pode ser notado, por exemplo, no folheto "Jesus, São Pedro e o ferreiro Rei dos Jogadores" de Manoel Caboclo e Silva, onde o ferreiro, depois de espoliado no jogo por um bando desonesto, torna-se, com ajuda do Diabo, jogador profissional, vingando-se dos seus inimigos, melhorando a sua situação financeira e assim explicando as razões da sua decisão ao São Pedro:

Disse São Pedro:/ - Coitado, perder a santa mansão,/ disse ele: - Eu sinto muito/ não ter de Deus o perdão,/ porém muito mais perdi/ pra essa corja de ladrão/ (....) Disse São Pedro:/ tu sabes, que o homem é subalterno,/ todo jogador não pode/ conversar com Deus eterno/, se perder, perdeu a alma,/ se ganhar é um inferno./ Disse ele: tens razão/, tua palavra é sagrada,/ porém do jeito que vivo/ não estou ligando nada,/ só eu sei o que padeço/ dessa corja condenada. ${ }^{16}$

No outro exemplo do pacto com Diabo para melhorar a vida, um estudante é movido pelo amor a uma jovem inacessível e o desejo de ascensão social para conquistá-la, apesar das suas origens humildes ("O estudante que se vendeu ao Diabo" de João Martins de Athayde).

No folheto "O homem que falou com o Diabo em Juazeiro" de João de Cristo Rei, aprendemos a história de um encontro de um farmacéutico com o Diabo que vem a Juazeiro para, movido de compaixão, salvar, por meio de uma missa que o farmacéutico manda celebrar conforme o pedido do Diabo, um padre condenado ao inferno por causa de uma praga atirada nele por um pai autoritário. No folheto, o Diabo, apesar de se autoapresentar como um ser poderoso e maldoso é mostrado pelo poeta como misericordioso, humanitário, próximo do homem, também bastante sofrido por causa dos erros cometidos na sua juventude (ele chegou a ser atacado com o facão pelo Arcangelo Miguel, quando se rebelou contra o seu Criador):

16 CABOCLO e SILVA, Manoel. Jesus, São Pedro e o ferreiro Rei dos Jogadores. (s.n.t., n.p) 
Fênix - Revista de História e Estudos Culturais

Janeiro - Junho de 2019 Vol.16 Ano XVI no 1 ISSN: $1807-6971$

DOI: $10.35355 / 0000016$

Disponível em: www.revistafenix.pro.br

("Tudo que é ruim no mundo/pertnece ao meu regimento/ a rixa, a briga, a discórdia/ desastre sanguinolento,/ filho desobediente,/ depravado e violento. (...) Infiltrei-me entre as nações/ para dar prosseguimento/ à contenda, à desavença/ o ódio, o espancamento/ sou eu o chefe invisível/ de todo acontecimento"). ${ }^{17}$

$\mathrm{Na}$ sua história o Diabo conta sobre os tempos quando substituía a Deus “(...)no trono da primasia,/ dominava o tribunal/ quando Jeová saía./ Quando Jeová saía,/ eu ficava autorizado/ para governar o trono/ na corte do seu reinado/, enquanto ele visitava/ outro país afastado" e criava sozinho anjos "sem se notar diferença/ dos que Jeová fazia". Até, num certo dia, ele recusou Jeová entrar de volta no seu próprio reino e sofreu a derrota, sendo mandado para o inferno de castigo:

Chegou Jeová em fim/ me pedindo para entrar/ eu disse: não lhe conheço,/ trate de se retirar/ este reino me pertence/ sou dono deste lugar (...) Jeová me respondeu:/ - A mim ninguém forma guerra/ vai morar no fogo eterno/ lá eu castigo quem erra/ chova anjo no inferno/ igual a chuva na terra (...) Eu desci com a negrada/ construí meu aposento/ preparei um fogo preto/ chamado constrangimento/ quem se achar lá comigo,/ dele não sai um momento. ${ }^{18}$

O Diabo conta também a história da tentativa de vingança por sua parte, quando voltou ao céu e foi atacado pelo Miguel:

(...) Miguel encostou-se a mim/ com a fala muito mansa/ juntou-me o pé na barriga/ empurrou também a lança./ Puxou o facão da cinta/ deume uma pisa safada/ deixou-me quase despido/ com a cabeça rachada,/ um buraco na barriga/ e uma perna quebrada. ${ }^{19}$

Ao descrever o inferno e as punições preparadas para os pecadores, o Diabo fornece os detalhes tenebrosos, como se quisesse amedrontar os ouvintes, prevenir a entrada deles no seu reino, dissuadir os homens de ir até lá, se mostrando ao mesmo tempo o causador, pela vontade e decisão de Deus ("Eu pedi um tempo a Deus,/ para governar na Terra,/ e ele me deu, dizendo:/ Pode começar a guerra"), das falhas humanas, e o punidor involuntário delas, um mero instrumento de Deus para castigar os infieis segundo a sui generis "teoria de retribuição", na qual o sofrimento e as desgraças

17 CRISTO REI, João. O homem que falou com o Diabo em Juazeiro. (s.n.y., n.p).

18 CRISTO REI, João. O homem que falou com o Diabo em Juazeiro. (s.n.y., n.p).

19 Ibid. 
se explicam como castigo por pecados cometidos (até por gerações passadas), e a felicidade e fortuna são vistas como "o prêmio" de Deus para os justos): "Os desastres que acontecem/ causando pena e horror/ sou eu quem estou fazendo/ castigando o pecador/ quem não escuta o seu Deus/ escuta a mim com rigor." Ao mesmo tempo, o Diabo está mostrando claramente o seu descontentamento com o papel de punidor que foi lhe designado por Deus: "Os castigos que tem lá/ para o povo condenado,/ eu não aviso por gosto,/ é porque sou obrigado/ quem viver no mal caminho,/ agora tome cuidado." 20

Num outro folheto, bastante famoso, relacionado com uma das canções de Roberto Carlos, na qual o cantor mandou tudo e todos para o inferno ("Carta de Satanás a Roberto Carlos" de Enéias Tavares dos Santos), o Diabo lamenta o ocorrido, explicando que ele já não tem condições para castigar mais pessoas, não tem lugar para todos que deveriam acabar no seu reino, e pede piedade aos homens, implorando a mudança no comportamento deles e dando exemplos concretos como deveriam e como não deveriam prosseguir:

Inferno, corte das trevas,/ meu grande amigo Roberto,/ eu vi o seu novo disco,/ é muito bonito, é certo,/ mas cumprindo a sua ordem/ o mundo fica deserto./ (...) mesmo porque no inferno/ não cabe mais esse povo,/ vai ficar tudo apinhado/ Apertado como um ovo/ E eu sou forçado a mandar/ fazer um inferno novo./ Pois minha situação/ não está de brincadeira,/ não há safra nem dinheiro/ só existe a quebradeira/ pare com essa cantiga/ que já me deu tremedeira./ (...) Pois o inferno já está/, por demais superlotado/, você ganhando o dinheiro/, e eu ficando aqui lascado./ (...) Pois aqui não tenho mais,/ comida nem aposento,/ tem trinta e duas mil almas/ só em um apartamento!/ Só de moça quase nua/ tem seiscentas e dez mil./ Onde é que eu boto esse/ Povo todo do Brasil?/ (...) Se não gostou do pedido/ aqui não quis lhe agravar/ Tentei apenas fazer/ ao meu amigo chegar/ nesta carta o meu horror,/ A mais cruciante dor,/ se não me crer venha olhar. ${ }^{21}$

No folheto do Antônio Teodoro dos Santos, “O Tú́ste no Inferno”, o Diabo, igualmente amistoso, acessível e compreensível, explica aos seus convidados as razões dos castigos aplicados aos condenados para o inferno, mostrando, ao mesmo tempo, como evitá-los:

20 CRISTO REI, João. O homem que falou com o Diabo em Juazeiro. (s.n.y., n.p).

21 TAVARES DOS SANTOS, Enéias. Carta de Satanás a Roberto Carlos. (s.n.t) 
- Este sangue aqui no tacho,/ Que você vê, inda quente,/ é o sangue nos hospitais/ Que se tira do vivente/ E passa ele no cobre/ Não aplica no doente./ Este que tem a corrente/ é a corrente secreta,/ que os homens da política/ a jogam como uma seta/ mata um derruba na meta./ Este tacho de dinheiro/ é o dinheiro da nação/ que só chega para os grandes/ deputado e tubarão/ eu ajunto todo aqui/ para uma apuração. Este da comida podre/Muito claro agora digo/ - E a comida que sobra/ E não dá ao mendigo/ Está guardadinha aqui/ Pra o avarento inimigo./ Este de roupa de moda/ E maiô, é biquinho/ E o "tomara que caia"/ A mãezinha no focinho/ Elas vêm todas diretas/ A este nosso cantinho./ Este aqui que está vazio/ E esperando o malvado/ Ladrão sem necessidade/ $\mathrm{O}$ assassino, o tarado/ $\mathrm{O}$ dançador de "tuíste"/ O roubador no mercado. ${ }^{22}$

Ele explica também aos seus visitas amedrontados, com paciência, as causas do Mal e a dialética das contradições da condição humana, defendendo Deus - seu próprio inimigo:

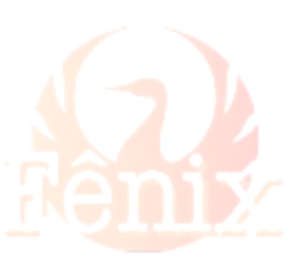

- Porque tanto sofrimento/ Deus ao homem desprezou?/ Assim Deus é bem malvado/ P'ra que ao homem criou?/ (...) Todo mal serve de bem/ você bem ouve o rifão/ Quem não sofre não aprende,/ quem sabe tem direção,/ E o sofrimento é que faz,/ As luzes no coração./ (....) Se Deus é justo não sei,/ Sei que é grande Criador,/ Fez beleza e harmonia,/ Fez a luz e esplendor,/ Mas alegria no homem/ só nasce depois da dor./ (...) Isto são coisas antônimas:/ Tem a treva e tem a luz,/ Tem o amargo e tem o doce/ o que amplia, o que reduz/ tem o que é conduzido,/ Tem aquele que conduz./ Tudo aqui já expliquei,/ E tudo assim é que é/ a vida humana é igual/ O vai e vem do maré,/ Envelhece, sabe muito,/ E a potência é dum bebê. ${ }^{23}$

Num outro folheto - "A mulher que foi surrada pelo Diabo" do Rodolfo Coelho Cavalcante, o Diabo, supreendentemente chamado de "um bom cristão", tenta dissuadir uma mulher casada, que se acha injustiçada em decorrência de relações conjugais, do que ela está planejando fazer e o que, segundo a opinião do Diabo, vai acabar mal para ela:

Irei percorrer o mundo,/ Pra minha vida gozar,/ Conhecer novas paragens/ Beber, fumar e dançar/ Ter a minha liberdade,/ para que a mocidade/ possa melhor desfrutar./ Já chega de lavar roupa,/ varrer casa e cozinhar,/ Quero sair pelo mundo,/ somente para gozar.../ sou moça, tenho saúde,/ Não perco minha juventude/ Escravizada num

22 DOS SANTOS, Antônio Teodoro. O Tuíste no Inferno. (s.n.t., n.p).

23 Ibid. 


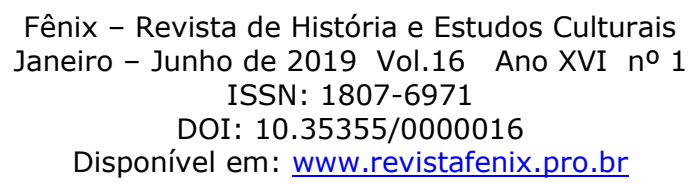

lar./ (...) Eu quero gozar no mundo/ Todos prazeres da vida.../ Cinco anos de casada/ eu já estou enjoada/ de só viver oprimida! ${ }^{24}$

O Diabo dá para ela conselhos e advertências, mas finalmente não consegue lhe convencer para ficar em casa - ela sai, acaba se prostituindo, mas depois se arrepende e recebe o perdão de Deus.

Um outro poeta, Luiz da Costa Pinheiro, no folheto intitulado "O casamento de Lusbel ou a História da Jumentinha e Maria Alice - a moça que enganada casou-se com o Diabo", descreve o Inferno como um lugar surpreendentemente aconchegante, bem organizado e administrado pelo ... Lampião, que, exaltado como herói popular, às vezes enfrenta nos folhetos da literatura de cordel o Demônio, tipicamente derrotando-o, ou simplesmente une as suas forças com o adversário de Deus, atuando no Inferno como seu co-adjuvante:

Ele disse que o inferno/ é uma cidade asseada/ Lampião é o prefeito/ e fez prraça ajardinada,/ está fazendo o calçamento/ e já tem água encanada./ Até luz de Paulo Afonso,/ Lampião já quer botar,/ com a filha de Lúcifer/ breve ele vai casar,/ e no dia do casamento/ ele quer inaugurar./ Em cada casa o prefeito/ está fazendo uma puxada/ pra botar moça enxerida/ da sobrancelha raspada/ mulher falsa e traiçoeira/ e viúva chumbregada. ${ }^{25}$

Finalmente, o poeta José Faustino Vila-Nova, na sua série de folhetos "Queixa de Satanás a Cristo”, coloca algumas conversas sugestivas entre o Diabo e Deus, que mostram, além da familiaridade, ou até uma certa intimidade entre os dois, a facilidade do acesso do Diabo a Jesus, que, aproximando-se a Deus sem problema nenhum, começa a queixar-se do desregramento atual do mundo, da grande quantidade de pecados cometidos que ele já nem precisa provocar e até não consegue controlar, falando também sobre a injustiça da sua própria condição do malfeitor em nome de Deus e do castigador impiedoso dos seres humanos, mencionando até a impossibilidade dele mesmo obter o perdão divino por suas próprias falhas e o pecado cometido que resultou na sua caída:

Meu Jesus o mundo velho/ está em grande aperreio,/ os homens estão sem cabestro/ e as mulheres sem freio,/ o pecado tomou conta,/ arrouxou de ponta a ponta,/ eu vou me montar no meio./ Eu pequei e

24 COELHO CAVALCANTE, Rodolfo. A mulher que foi surrada pelo Diabo. (s.n.t., n.p)

25 DA COSTA PINHEIRO, Luíz. O casamento de Lusbel ou a História da Jumentinha e Maria Alice - a moça que enganada casou-se com o Diabo. (s.n.t., n.p) 


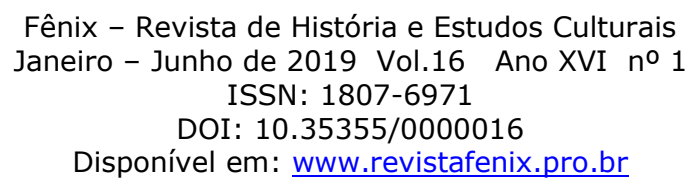

me perdi/ o perdão não pude achar,/ como é que o pecador/ capaz de observar/ a vossa lei sacrossanta,/ joga, dança e pinta manta,/ como pode se salvar? ${ }^{26}$

O poeta coloca a Virgem Maria como a pessoa que interrompe a conversa e manda o Diabo, impiedosamente, de volta para o inferno, onde ele, desesperado com o insucesso de seu protesto e com a falta dos resultados da sua conversa, desabafa, humilhado por Deus e sua mãe:

Eu me retiro porém/ ninguém se queixe de $\mathrm{mim} /$ porque vou dizer ao povo/ que só faça o que for ruim./ Vou mandar gente jogar/ desonrar, matar, beber,/ não ir nunca à igreja/ roubar quando for vender/ tudo aqui é perdoado/ pois o mal pode fazer. ${ }^{27}$

Assim, como explica Derrida quando nos alerta para o facto de que o demónio, até tentando ser bom, sempre é simplesmente uma ótima "desculpa" para Deus, uma boa razão para a existência do Mal, da injustiça e da infelicidade humana, "o mal radical pode ser útil, a destruição infinita pode ser reinvestida numa teodiceia, o demónio também serve para justificar." 28

\section{CONClUSÃo}

Toda cultura, de uma forma ou de outra procura personificar a maldade (tanto quanto a bondade), dando-lhe face e personalidade. Na cultura judaico-cristã foi sempre o Diabo que encarnaria todo o mal, mas as religiões não-cristãs, com os seus espíritos do mal, também ofereceram o estoque simbólico necessário para a sua identificação. $O$ Diabo constitui, portanto, somente uma das feições do mal, mas talvez a mais conhecida de todas. Por isso, não é provável que ele desapareça da vida humana e da cultura e os seus produtos literários, inclusive no Brasil, onde vemos claramente a importância dele nos fragmentos citados das obras de literatura de cordel. Ele constitui, no simbolismo religioso do sertão, figura central. Sua presença é marcante não somente enquanto justificativa de todo pecado e de toda frustração, desgraça e infelicidade que possam vir a ocupar a vida do homem. Embora fragmentos de alguns dos folhetos aqui citados

26 VILA-NOVA, José Faustino. Queixa de Satanás a Cristo. (s.n.t., n.p)

27 VILA-NOVA, José Faustino. Queixa de Satanás a Cristo. (s.n.t., n.p)

28 DERRIDA, Jacques. Archive Fever: A Freudian Impression. Trad. E. Prenowitz, University of Chicago Press: Chicago, 1998, p. 13. 
preservem, pelo menos parcialmente, um caráter tenebroso, com o objetivo pedagógico de ensinar sobre as consequências do pecado e fazer os homens se arrependerem, a figura do Diabo é, como pretendi mostrar, não tão ortodoxamente apresentada de uma maneira claramente pejorativa em muitas das histórias contadas em verso. O Diabo aparece, às vezes, supreendente na sua cordialidade e acessibilidade, como alguém desinteressado na sua tentativa indiscriminatória de, paradoxalmente, proteger os homens do mal, do pecado, do Inferno, de si mesmos. Podemos observar que as "brincadeiras verbais" dos poetas populares nordestinos com o Diabo possuem muitas incompatibilidades com a fé cristã e a doutrina católica, aliás incompatibilidades típicas para quase todos os fenômenos característicos da religiosidade popular. Além de apresentar um Deus distante, às vezes desinteressado no mundo humano, eles endossam um perfil diabólico bastante positivo, subestimando o lado maligno do Demôniomonstro, que normalmente só aterroriza, tenta e assusta. Porém, seria também exagero dizer que o folhetos aparentam uma obra feita somente "com amor ao amigo Diabo", àquele que o cristão tem que se opor. Ele é simpático e compreensível, mas a visão do inferno, excluindo talvez os casos do lugar sob a gestão do Lampião, permanece suficientemente tenebrosa para não atrair.

O bom Diábo da literatura de cordel age, no entanto, ao contrário do que deveria fazer cumprindo o seu papel principal da personificação e emanação do Mal no cristianismo. Embora ele, como já mencionamos, mantenha a possibilidade de assombrar, ele é uma criatura que interage facilmente com os indivíduos como se fosse um ser humano, ele se aproxima das pessoas com muito mais facilidade do que Deus e os seus santos. Não tanto figurando como uma entidade perversa, capaz de arrebatar a alma, como acontece em "Grande Sertão: Veredas" de Guimarães Rosa, mas como uma figura rebelde, inteligente, às vezes irônica. Noutras ocasiões grotesca, mas também sábia e paciente, capaz de explicar a necessidade da existência do mal e do sofrimento no mundo expondo argumentos razoáveis e lógicos, surpreendentemente defendendo também o seu Criador das críticas por parte daqueles que permanecem condenados à luta eterna entre o bem e o mal, entre o sagrado e o profano. Mas, como explica Olávio Bilac no seu famoso ensaio sobre o Diabo brasileiro, postulação de um demónio absolutamente mau não é, na verdade, nenhuma necessidade lógica: tanto Deus, como o Demónio são simplesmente polarizações do Bem e do Mal que estão inscritas na 


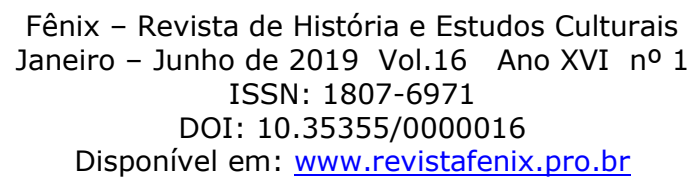

tradição judaico-cristã. ${ }^{29}$ A persistência e pertinência do "demoníaco" continua, no entanto, presente, unindo, na crença no Diabo, muitos elementos do vasto panorama religioso brasileiro. Como comenta Ronaldo de Almeida,

O diabo é a figura do universo cristão em que são enquadradas todas as divindades das outras religiões, tornando-se, paradoxalmente, o articulador da continuidade entre as crenças e da circulação de pessoas por esse caldo religioso católico-afro-espírita-pentecostal. ${ }^{30}$

O Diabo continua sendo, portanto, constantemente evocado pelos representantes da literatura popular brasileira do Nordeste, às vezes com o seu lado lúdico, noutras situações positivo conforme tentei apresentar aqui. Mas sempre com as características inerentes do mundo social e cultural dos autores dos folhetos e dos seus ouvintes (leitores). Como nos explica Bilac, "tão certo é que cada homem imagina o Diabo de acordo com o seu próprio temperamento..."31, ou, como poderíamos simplificar para os nossos fins: cada pecador tem a sua própria ideia do Demónio que lhe atormenta. Mas surpreendentemente, às vezes é este Demônio que se pode tornar, paradoxalmente, seu grande amigo, um bom companheiro, parceiro, sócio, ou até um excelente professor que, com paciência e sabedoria mostra o significado das coisas, ensina sobre o valor verdadeiro da vida e sobre o custo dos prazeres, pecados e enganos.

RECEBIDO EM: 24/01/2019 PARECER DADO EM: 08/03/2019

29 BILAC, Olavo. O Diabo, Conferência Literárias. Rio de Janeiro: F. Alves \& Cia, 1912, pp. 129.

30 ALMEIDA, Ronaldo de. Pombas-Giras, Espíritos, Santos e Outras Devoções, Novos Estudos CEBRAP 57, São Paulo, 2000, p. 199.

31 BILAC, Olavo. O Diabo, Conferência Literárias. Rio de Janeiro: F. Alves \& Cia, 1912, p. 161. 
Fênix - Revista de História e Estudos Culturais

Janeiro - Junho de 2019 Vol.16 Ano XVI no 1

ISSN: $1807-6971$

DOI: $10.35355 / 0000016$

Disponível em: www.revistafenix.pro.br 